Brit. Heart f., 1968, 30, 514.

Our knowledge of the natural history of most malformations of the heart is far from complete, mainly because their clinical diagnosis interested so few physicians for any length of time before their surgical treatment became possible. This hampered the study of their natural history because the more severe cases, in varying degrees, were submitted to operation, and most early papers were reports of one or two cases with necropsies. Thus, Thursfield and Scott (1913) reported the sudden death of a boy of 14 with subaortic stenosis: 7 years earlier the diagnosis had been a ventricular septal defect. Christian (1933) reported two congenital defects, one subvalvar in a man of 40 and the other valvar in a man of 27 years, both of whom had died.

An unduly pessimistic view was formed from Maude Abbott's 23 necropsies with aortic stenosis among 1000 with all forms of cardiac malformations (Abbott, 1936). The stenosis was subvalvar in 12 and valvar in 11, the mean age at death for the former being 23 years (oldest 58) against 4 years (oldest 24) for the latter. Probably the older patients with valvar stenosis were classified as rheumatic or as calcific aortic stenosis. Most clinical accounts, on the other hand, were too optimistic. Gallavardin (1936) thought most of his 50 patients got on well and reported only 2 deaths, both in the fourth decade, but he does not seem to have followed the patients and probably missed some who died suddenly. Young (1944) described 10 men with aortic stenosis who served in the army with little difficulty. They were found among 18,000 soldiers, an incidence of 0.05 per cent, and Young reported them as having subaortic stenosis but gave no reason for this.

Grishmann, Steinberg, and Sussman (1947) reported 23 patients, including 3 who had died aged 4,9 , and 48 , and one man aged 33 who had led a very active life till the onset of angina at 28; apart from these, they gave insufficient details to help

Received July 25, 1967. with the natural history. Kiloh (1950) reported 50 cases of pure aortic stenosis without any deaths, but reached no conclusion about the aetiology. Brown (1950) and Wood (1950) both repeated that the prognosis was relatively good for subvalvar stenosis, and the latter added that most subjects with aortic valvar stenosis died young.

Campbell and Kauntze (1953) reported 40 cases with only 2 deaths, both after aortic valvotomy. They did, however, refer to 8 deaths that Dr. Keith Simpson could remember among the many coroner's necropsies he had performed, and the hearts from 2 of these children who had died suddenly were described and illustrated.

This general optimism was probably due to a failure to learn that many of the younger patients had died suddenly, and to recognize the aortic stenosis as congenital in the older ones.

\section{Present Series}

In the present series of 87 patients, it seems best to distinguish (1) the 69 in whom the murmur of congenital aortic stenosis was recognized before they were 20 , and (2) the 18 in whom it was not. The case numbers of these 18 are, therefore, distinguished by the suffix "B" (i.e. Cases 38B-40B, and 76B-90B). Probably in many of these 18, especially those in whom the murmur was heard at about the age of 20-22 and led to rejection for army service, the aortic stenosis was congenital and it was fortuitous that the murmur had not been noted or recorded earlier. Probably in some others, especially those in whom it was first heard at about 40 , often with symptoms that demanded an operation, the stenosis had developed gradually on bicuspid valves. Observation of many young people over a long period will be needed to settle this question, which is being discussed more fully elsewhere (Campbell, 1968).

These 87 patients are made up of 50 not reported previously, and 37 of the 40 cases of Campbell and Kauntze (1953). It was hard to decide if some of 
TABLE I

AGES WHEN MURMUR FIRST HEARD AND WHEN PATIENTS FIRST AND LAST SEEN

\begin{tabular}{|c|c|c|c|c|c|c|c|}
\hline & \multicolumn{7}{|c|}{ No. of patients in each age-group } \\
\hline & 5 and under & $6-10$ & $11-19$ & $20-29$ & $30-39$ & $40-49$ & 50 and over \\
\hline $\begin{array}{l}\text { When murmur first heard, } 87,69+(18) \\
\text { When patient first seen } \\
\text { When follow-up ended; all patients, } \\
\text { including (a) and (b) below } \\
\text { (a) By death } \star \star 15+\text { ( } 7 \text { ) } \\
\text { (b) By operation } 22+\text { (5) }\end{array}$ & $\begin{array}{l}41 \\
12 \\
- \\
-\end{array}$ & $\begin{array}{r}17 \\
15 \\
7 \\
2 \\
3\end{array}$ & $\begin{array}{r}11 \\
17 \\
17 \\
3 \\
9\end{array}$ & $\begin{array}{l}(8)^{\star} \\
20+(1) \\
2 \\
2 \\
2\end{array}$ & $\begin{array}{l}(4)^{\star} \\
8+(4) \\
11+(2) \\
2+(1) \\
4+(1)\end{array}$ & $\begin{array}{l}(6)^{\star} \\
5+(9) \\
10+(11) \\
3+(3) \\
4+(3)\end{array}$ & $\begin{array}{l}-\overline{0}(4) \\
4+(5) \\
3+(3) \\
0+(1)\end{array}$ \\
\hline
\end{tabular}

* The numbers shown in brackets denote those 18 where the murmur was not known to have been present before 20 years of age.

$\star \star$ The mean age at death of the 8 patients who died suddenly was 30, and of the other 14 it was 44 years. The mean for all 22 patients was $38 \cdot 7$ years.

these patients (e.g. Cases 38-40 of Campbell and Kauntze), whose murmur was not known to have been present before 37 years of age, had aortic stenosis that was congenital or that had developed from bicuspid aortic valves as they became more rigid or calcified. The remaining 3 of the 40 patients are excluded, 2 because they had isolated dextrocardia, and the third because, after recovery from anaemia, her aortic stenosis was not certain.

Both valvar and subvalvar stenosis are included since they were not often distinguished with certainty without operation or necropsy. Among them, 7 were known to be subvalvar and 33 valvar, including one in each group who had both. This proportion of 1 subvalvar to $4 \cdot 7$ valvar is rather more than the 1 to 6 (84 to 507) found in the combined series marked in the list of references.

Among our patients, 65 were male and 22 were female, a proportion of 3 to 1 that agrees with 733 to 231 in the combined series.

The decades when the murmur was first heard, and when the patient was seen for the first and last time, are shown in Table I. The mean age increased from 23 to 31 years, but their ages cover a wide range which helps to give a broad view of the problem. In those in whom the aortic stenosis was certainly congenital, the murmur had been heard by 5 years of age in 60 per cent, and by 10 years in 84 per cent.

Only 5 patients (Cases $5,12,18,24$, and 28 ) gave any history of acute rheumatism, and in all of them the murmur had been heard before the onset of the rheumatism. None of these 5 had any evidence of disease of the mitral valve, and in the 2 who died the mitral valve was normal at necropsy.

The follow-up started when the patient was seen by myself or, occasionally, by a colleague. Clearly, if a patient was well when I first saw him, he had done well up to that time, but the previous years were not included because the number of his contemporaries who had died or done badly cannot be known. In 22 patients the follow-up was brought to an end by death, and in 27 by aortic valvotomy. Whether or not the operation was successful, time after it has been excluded. Seven of the deaths and 3 of the operations took place within 2 or 3 years of the start of the follow-up.

The main follow-up was completed in 1957-8, when nearly all of those who were still alive were reexamined. Only 8 of the 87 patients were lost sight of during the first 2 years of their follow-up, but even this added a glimpse of their condition. I am greatly indebted to my colleagues at Guy's Hospital and at the National Heart Hospital for their help in allowing me, in 1966, to add the record of the intervening years, where possible. In all, these 87 patients have been followed for 782 patient-years: 34 have been seen for 10 years or more, including 8 seen for more than 20 years, and 2 for 32 years. Sixty-nine in whom the stenosis was certainly congenital have been followed for an average of $10 \cdot 2$ years, but 18 in whom it was less certainly congenital for only $4 \cdot 3$ years.

Patients attending a hospital clinic are not the ideal unselected population for a study of the natural history of aortic stenosis, but no other basis seems to be available. Many of these patients, however, were seen because a murmur had been heard at a routine examination, most often at school or for service in the armed forces, 16 mainly because of the murmur and 25 with some symptoms also. In 22 others the symptoms were more severe and in 24 they were serious, and naturally these patients did not do so well. Eight died, all adults, 6 within 3 years, but 2 after 5 and 10 years, and 13 had aortic valvotomy which excluded them from further follow-up. This balances to some extent those who were seen only because they had symptoms that proved fatal.

Left Ventricular Systolic Pressures and Aortic Gradients. All these patients were seen before 1957-8, when my charge of them ended, and much of the discussion will seem old-fashioned because of the scanty information existing then about these im- 
TABLE II

RELATION OF T INVERSION IN V6 AND AORTIC GRADIENT AND LV SYSTOLIC PRESSURE

\begin{tabular}{|c|c|c|c|}
\hline & $\mathrm{T}$ in V6 & $\begin{array}{c}\text { Gradient (peak systolic) } \\
\text { (mm. Hg) }\end{array}$ & $\begin{array}{c}\text { LV systolic pressure } \\
(\mathrm{mm} . \mathbf{H g})\end{array}$ \\
\hline Children (up to 17) & $\begin{array}{l}\text { Inverted } \\
\text { Inverted or upright } \\
\text { Upright }\end{array}$ & $\begin{array}{l}\text { Generally }>65 \\
\text { From } 60 \text { to } 95 \\
\text { Generally }<90\end{array}$ & $\begin{array}{l}\text { Probably }>165 \\
\text { Probably }<165\end{array}$ \\
\hline Adults & $\begin{array}{l}\text { Inverted } \\
\text { Inverted or upright } \\
\text { Upright }\end{array}$ & $\begin{array}{l}\text { Generally }>45 \\
\text { From } 40 \text { to } 70 \\
\text { Generally }<50\end{array}$ & $\begin{array}{l}\text { Probably }>145 \\
\text { From } 145 \text { to } 165 \\
\text { Probably }<165\end{array}$ \\
\hline
\end{tabular}

portant pressures. Most of the operations were blind valvotomy, with its risk of aortic regurgitation (Baker and Campbell, 1956), and only in a few, after 1956, was open valvotomy under hypothermia performed.

Percutaneous left ventricular puncture became possible about this time (Brock, Milstein, and Ross, 1956; Fleming and Gibson, 1957), mainly as a preoperative proceeding, and a few of these patients have had this since. In general, the pressures were known only in those who had operations, and nearly all these had severe stenosis. In 12 children the mean gradient was $123 \mathrm{~mm}$. $\mathrm{Hg}$, with a mean left ventricular systolic pressure of $212 \mathrm{~mm}$. $\mathrm{Hg}$, and in 12 adults these were only a little lower, 105 and $198 \mathrm{~mm}$. Hg. In these 24, the gradient (peak systolic) was between 155 and $180 \mathrm{~mm}$. $\mathrm{Hg}$ in 2, between 100 and 142 in 14, between 87 and 94 in 6, and below this ( 80 and $68 \mathrm{~mm} . \mathrm{Hg}$ ) in 2 only.

It is, however, possible to deduce the rough range of the gradient. Hancock and Fleming (1960) thought the left ventricular systolic pressure had the best correlation with the severity of the stenosis. Excluding their 10 with significant regurgitation, I have reached the following conclusions.

When $\mathrm{T}$ in V6 was inverted in their children (age 16 and under), the left ventricular systolic pressure was over $165 \mathrm{~mm} . \mathrm{Hg}$ and the gradient at least 65 $\mathrm{mm}$. $\mathrm{Hg}$, though sometimes it had to be as high as $90 \mathrm{~mm}$. $\mathrm{Hg}$ to cause inversion. In adults, left ventricular systolic pressure was always $140 \mathrm{~mm}$. $\mathrm{Hg}$ or more and the gradient $40 \mathrm{~mm}$. Hg or more.

When T in V6 was upright, left ventricular systolic pressure was nearly always under $165 \mathrm{~mm}$. Hg, but was $185-190 \mathrm{~mm}$. $\mathrm{Hg}$ in 1 child and 1 adult. The gradient was generally $45 \mathrm{~mm}$. Hg or less, but was $70 \mathrm{~mm} . \mathrm{Hg}$ in 2 adults and 1 child out of their 15 cases.

Among the children of Edwards and Jones (1962), aged 4-17 years, $T$ wave inversion always meant a gradient of at least $60 \mathrm{~mm}$. $\mathrm{Hg}$, but many children with gradients between 60 and $100 \mathrm{~mm}$. Hg still had upright $T$ waves (their Fig. 5). In their adults (over age 26), it nearly always meant a gradient of at least $50 \mathrm{~mm}$. Hg. However, an upright $\mathrm{T}$ wave almost excluded (only 1 of 25 cases) a gradient of $60 \mathrm{~mm}$. Hg or more, and excluded one of more than $80 \mathrm{~mm}$. Hg (their Fig. 6).

These two papers, which are of great value in other ways also, are in general, though not complete, agreement. From Table II of the present paper one can see if the pressure is likely to be above or below a certain level. This is as far as one can go. Though the depth of the $T$ wave inversion increases from a mean of 3 to $9.5 \mathrm{~mm}$. as the left ventricular systolic pressure rises from 155 to 275 $\mathrm{mm}$. $\mathrm{Hg}$, the range of variation is much the same at all levels of pressure.

Abdin (1958) also thought the $T$ wave inversion in V6 was closely related to the severity of the stenosis in 19 necropsies. Epstein and Coulshed (1964) found that some features of the external carotid pulse tracings could be used in the same way, but with a good deal of overlapping. Gamboa, Hugenholtz, and Nadas (1965) thought the magnitude of the maximal spatial (Frank) vector was an even better indicator than the $T$ wave inversion.

\section{Natural History of First Two Years}

This section is based on the experience of others, three series in which all children born in certain areas with malformations of the heart were followed for some years. This allowed a study of the early mortality and a correct diagnosis in a large proportion. Downing (1956), among others, has emphasized that with aortic stenosis the correct diagnosis may not always be possible for 3 or 4 years.

These series are (1) MacMahon, McKeown, and Record (1953), (2) Carlgren (1959), and (3) J. Hay and $R$. W. Smithells (1965, personal communication about unpublished figures). They comprised only 39 infants with a diagnosis of aortic stenosis, and $14(36 \%)$ died, mostly in the first, or, less often, in the second year of life, and most of them with congestive heart failure. This estimate is too high as the slighter cases would tend to be missed. The mortality in a paediatric clinic is, on the other hand, too low, because many severely affected patients will 
TABLE III

MAIN FINDINGS OF FOLLOW-UP IN EACH DECADE

\begin{tabular}{|c|c|c|c|c|c|c|c|}
\hline Decade & No. of patients & $\begin{array}{l}\text { Patient } \\
\text { years of } \\
\text { follow-up }\end{array}$ & $\begin{array}{l}\text { Sudden } \\
\text { deaths }\end{array}$ & All deaths & $\begin{array}{l}\text { Patients with } \\
\text { serious signs of } \\
\text { deterioration }\end{array}$ & $\begin{array}{l}\text { Patients with } \\
\text { unfavourable } \\
\text { signs but } \\
\text { seeming well }\end{array}$ & $\begin{array}{l}\text { Patients } \\
\text { doing well }\end{array}$ \\
\hline $\begin{array}{l}\text { 1st } \\
\text { 2nd } \\
\text { 3rd }\end{array}$ & $\begin{array}{l}24^{\star} \\
20+15 \\
12+17\end{array}$ & $\begin{array}{r}93 \\
213 \\
182\end{array}$ & $\begin{array}{l}2 \\
2 \\
0\end{array}$ & $\begin{array}{l}2(8)+ \\
3(8) \\
2(7)\end{array}$ & $\begin{array}{l}5(21) t \\
9(26) \\
5(17)\end{array}$ & $\begin{array}{l}5(21) t \\
9(26) \\
9(31)\end{array}$ & $\begin{array}{l}12(50) \dagger \\
14(40) \\
13(45)\end{array}$ \\
\hline $\begin{array}{l}\text { 1-3rd } \\
\text { 4th } \\
\text { 5th } \\
\text { 6th }\end{array}$ & $\begin{array}{c}56+32 \\
12+9 \\
15+9 \\
4+4\end{array}$ & $\begin{array}{r}488 \\
124 \\
125 \\
45\end{array}$ & $\begin{array}{l}4 \\
1 / 0 \\
0 / 2 \\
1 / 0\end{array}$ & $\begin{array}{c}7(8) \\
2 / 1(14) \\
3 / 3(25) \\
3 / 3(75)\end{array}$ & $\begin{array}{l}19(22) \\
7 / 1(38) \\
4 / 4(33) \\
0 / 2(25)\end{array}$ & $\begin{aligned} & 23(26) \\
& 5 / 1(28) \\
& 3 / 1(17) \\
& 0\end{aligned}$ & $\begin{array}{c}39(44) \\
3 / 1(20) \\
2 / 4(25) \\
0\end{array}$ \\
\hline Total & 87 & 782 & 8 & $22(25)$ & & & \\
\hline
\end{tabular}

* The second figures are those patients carried on from one or more of the earlier decades.

+ The figures in brackets show the percentages with that condition in each decade. This divides the number with congenital aortic stenosis from those in whom it may have developed on congenital bicuspid valves (see text).

have died without being seen at the clinic. Keith, Rowe, and Vlad (1958) found a mortality of 10 per cent. The true figure must, therefore, be between 15 and 31 per cent, probably $23 \pm 5$ per cent. There is certainly a very heavy mortality in the first year of life, and no doubt more accurate figures will become available.

\section{Condition of the Patients in Decades}

A measure of the time the subjects are under observation, as well as their number, is essential for an expression of the mortality. The 782 patientyears during which these 87 patients were followed is enough to allow some account of their progress in each decade. Many were seen in two or three decades and their condition changed considerably. The patients have been divided into four groups.

(1) Those who were doing well as regards both signs and symptoms. Moderate left ventricular hypertrophy with upright $T$ waves and no $S-T$ depression did not prevent their inclusion in this group.

(2) Those who seemed well but had some signs that were unfavourable for the future. Flat or biphasic $T$ waves or slight $S-T$ depression in the left chest leads, early signs of left ventricular strain, and increasing dyspnoea were the most common reasons for inclusion.

(3) Those with angina pectoris or effort syncope, more serious aortic regurgitation with a widening pulse pressure, moderate or severe signs of left ventricular strain, or congestive heart failure, though the last was rarely the first reason for inclusion. T wave inversion or S-T depression, generally of 2 $\mathrm{mm}$. or more, often with angina, was the commonest reason for inclusion.

(4) Those who died, excluding those who died after operation.
The main findings in each decade are summarized in Table III.

First Decade. 24 patients. (1) Twelve (50\%) were doing well, leading a normal life without any unfavourable signs or symptoms; but this did not prevent 4 of them moving to a lower group in the next decade. (2) Five seemed well but had some unfavourable sign or increasing dyspnoea. (3) Another 5 had more severe signs, most often moderate or severe left ventricular strain, generally with angina. In 3 of these the follow-up was ended by aortic valvotomy and without this they, and many similar patients in later decades, would not have lived for long. (4) Two (8\%), both aged 9, died suddenly. The death rate (2 in 93 patient-years) was $2 \cdot 1$ per cent per annum.

Second Decade. 35 patients (20 new and 15 carried on from the first decade). (1) Fourteen (40\%) were doing well, but 2 of these developed serious signs in the next decade. (2) Nine seemed well but had some unfavourable signs, most often left ventricular strain. (3) Nine had moderate to severe left ventricular strain, generally with angina or increasing dyspnoea. At aortic valvotomy, which ended their follow-up, all 9 had a gradient of 100 $\mathrm{mm}$. Hg or more except 1 in whom it was $80 \mathrm{~mm}$. Hg. (4) Three died, 2 suddenly and 1 after bacterial endocarditis (Case 57). These 3 deaths in 213 patient-years give a mortality of 1.4 per cent per annum.

Third Decade. 29 patients (12 new and 17 carried on). (1) Thirteen ( $45 \%$ ) were still doing well but 2 lost ground in the next decade. (2) Nine seemed well but had some unfavourable signs. (3) Only 5 had serious signs, one a large heart with aortic regurgitation, and the others moderate to severe left 


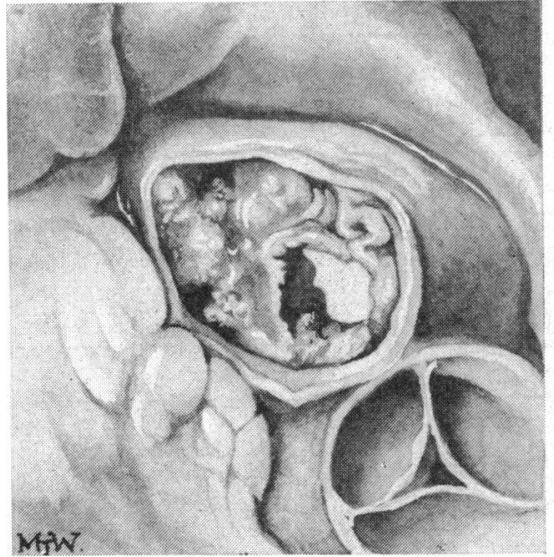

(A)

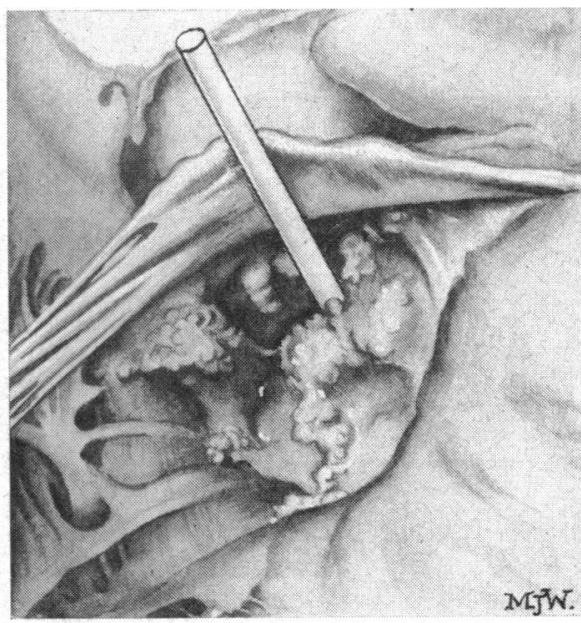

(B)

FIG.-The aortic valve of Case 26, aged 24. Calcification of the valve had been noted on radioscopy six years before. (A) From above, calcification is easily seen but the stenosis does not look very severe. (B) From below, a probe has been passed through the opening and the stenosis looks more severe. When the heart was held this way with the valve at the bottom, water trickled through only very slowly.

ventricular strain. Two of them had seemed well at the start of the decade. Two, both with angina, had aortic valvotomy. (4) Two (Cases 26 and 28) died and are reported below as examples of the possible seriousness of stenosis that did not seem severe in the previous decade. The 2 deaths in 182 patient-years give a mortality of 1.1 per cent per annum.

Calcification of the aortic valve is increasingly common during the third decade. Fig. 1 of Campbell and Kauntze (1953) showed it at 18 years in Case 26 and it was confirmed at necropsy 8 years later. About the end of this decade it becomes more common for the valve to be calcified than non-calcified.

Case 26, aged 18-24 years, led a normal life except that he did not play games at school. At 18, slight left ventricular hypertrophy only; calcified aortic valve. At 21 , working as a surveyor, but some angina on running. $T$ wave nearly flat in lead $I$, late rising in V 5 , and inverted in V7. Average blood pressure $117 / 79 \mathrm{~mm}$. Hg. At 24 he developed congestive heart failure rather suddenly. His left ventricular hypertrophy $(18+21)^{\star}$ hardly increased, $T$ wave flat in lead $\mathrm{I}$, with $2 \mathrm{~mm}$. inversion in V5 and V7. Three days after admission he died suddenly in bed.

At necropsy the heart weighed $800 \mathrm{~g}$. Aortic valve grossly nodular, calcified, and probably bicuspid, with an opening 13 by $9 \mathrm{~mm}$. Seen from above (Fig. A),

* The figures in brackets are the size in $\mathrm{mm}$. of $\mathrm{S}$ in $\mathrm{V1}$ and of $R$ in V5 or V6. the stenosis did not appear extreme, but viewed from below (Fig. B) it did. When the left ventricle was held upwards, to form a cup with the valve at its base, water trickled only slowly through the valve which was obstructed by the calcified masses. This may have been the cause of his death as the coronary arteries and their mouths were not obstructed.

Case 28, aged 24-28 years, a little breathless when rejected for the army at 18 . Still the same at 24 , with left ventricular hypertrophy and T wave nearly flat in lead V7 but normal in leads I and V5. At 25, some angina on running; aortic valve calcified; average blood pressure 126/104 mm. Hg. When 28 (February 1952), angina was more frequent and the $\mathrm{T}$ wave in lead V5 had become inverted. By May, there was increasing dyspnoea and oedema of the ankles. In June, severe prolonged chest pain was experienced. Fourteen days later he was admitted to hospital with gross congestive failure and recent anterior cardiac infarction, and he died suddenly 2 days later.

At necropsy, the heart weighed $700 \mathrm{~g}$. and the aortic valve was severely distorted, stenosed, and calcified. Extensive, fairly recent, anterior infarct. Coronary arteries normal except that, $1 \mathrm{~cm}$. from the origin of the left one, a nodule of calcium, about 1 by $0.5 \mathrm{~cm}$., with adherent ante-mortem thrombus, was obstructing the lumen. The infarct seemed to have been caused by the small calcific nodule embolizing from the aortic valve.

Soulié et al. (1964) think that such emboli are not uncommon. They reported 3 cases with multiple emboli, several macroscopic and many microscopic. In 1 case, at least, such an embolism had lodged in a coronary artery and caused a cardiac infarction. 
TABLE IV

SUDDEN DEATHS AND ALL DEATHS IN CHILDREN EXCLUDING EARLY INFANCY

\begin{tabular}{|c|c|c|c|}
\hline \multirow[t]{2}{*}{ Authors } & \multirow{2}{*}{$\begin{array}{l}\text { No. of patients } \\
\text { and average years } \\
\text { of observation }\end{array}$} & \multicolumn{2}{|c|}{$\begin{array}{l}\text { Percentage and number (in brackets) } \\
\text { of deaths per annum }\end{array}$} \\
\hline & & From all causes & Sudden deaths \\
\hline $\begin{array}{l}\text { Landtman et al. (1966) } \\
\text { Edwards and Jones (1962) } \\
\text { Campbell (aged 3-19) } \\
\text { Marquis and Logan (1955) } \\
\text { Braverman and Gibson (1957) } \\
\text { Ongley et al. (1958) }\end{array}$ & $\begin{array}{c}102 \times 5=510 \\
115 \times 12=1395 \\
44 \times 7=306 \\
28 \times 4=112 \\
73 \times 4=292 \\
67 \times 3=201\end{array}$ & $\begin{array}{l}1 \cdot 2(6) \\
0 \cdot 8(11) \\
1 \cdot 6(5) \\
4 \cdot 5(5) \\
2 \cdot 1(6) \\
2 \cdot 5(5)\end{array}$ & $\begin{array}{l}0 \cdot 4(2) \\
0 \cdot 4(6) \\
1 \cdot 3(4) \\
2 \cdot 7(3) \\
1 \cdot 7(5) \\
2 \cdot 0(4)\end{array}$ \\
\hline Total & $429 \quad 2816$ & $1 \cdot 4(38)$ & $0.9(24)$ \\
\hline
\end{tabular}

Fourth Decade. 21 patients (12 new and 9 carried on), who were much less well than those in the first three decades. (1) Only $4(20 \%)$ were still doing well. (2) Six seemed to be well but had some unfavourable signs; most of these, and 2 of the 4 in group (1), lost ground in the next decade. (3) Eight patients made this the largest group for the first time, 5 of them had aortic valvotomy, and 1 died in the next decade. (4) Three died, 1 suddenly, and 2 with congestive failure. These 3 deaths in 124 patient-years give a mortality of 2.4 per cent per annum, double that in the second and third decades. Neglecting 2 patient-years of Case 77B from 27-29, this is the first decade to include $B$ patients in whom the stenosis may have been congenital or may have developed from bicuspid valves. There was one of these B patients in each of the $\mathbf{4}$ groups, these being shown by the second figure after the stroke in Table III.

Fifth Decade. 24 patients (15 new and 9 carried on). In this and the next decade, about half the cases belonged to the B group. They are separated in Table III but discussed with the others as their progress seemed similar. (1) Six (25\%) were still doing well; their follow-up was only short in 3, but between 20 and 26 years in the other 3: one was still well at 48 (Case 77B), and 2 died (Cases 52 and 71). (2) Four seemed well but had some unfavourable signs. (3) Eight had serious signs or symptoms and 3 of them would probably have died soon without aortic valvotomy. (4) Of 6 who died (25\%), 2 died suddenly and 4 from congestive heart failure. These 6 deaths in 125 patient-years give the very high mortality rate of 4.8 per cent per annum. Four of the deaths were in patients who had been followed for a long time-32,15,11, and 10 years (Cases 30, 27, 80B, and 39B, respectively). Another man, who died at 44 after 32 years of follow-up, has not been included here because he was getting on well till shortly before his death from pneumonia and a re- crudescence of tuberculosis of the lung (Case 70)the only known death from a non-cardiac cause in the series.

Sixth Decade. 8 patients (4 new, all group B, and 4 carried on). None were now doing well, or even seeming to do so. (3) Only 2 were living with serious signs or symptoms; and (4) 6 died. The mortality rate in 45 patient-years, 13 per cent per annum, is so high that it cannot be representative of any group. Of the 6 patients who died, 3 had been followed for 20,26, and 28 years and were doing well till the last few years of their lives (Cases 52, 54, and 71). The first and last of these lived till the seventh decade, dying at 63 and 62 years, respectively. The other 3 were $B$ cases with only short follow-up, but their murmurs had been heard at 20,27 , and 28 years of age.

This concludes our series of patients. Probably those dying at $\mathbf{7 0}$ and $\mathbf{8 0}$ with aortic stenosis are more likely to be those in whom changes in the valve, often a bicuspid one, have caused the stenosis after $\mathbf{4 0}$ or not long before this age.

\section{EXPECTATION OF LIFE FOR THOSE WITH Congenital Aortic STENosis}

There are two series of almost unselected children and three others of children attending hospital clinics, as well as my series (Table IV). In all of these we know how long the children were under observation and can calculate the patient-years at risk from the data given.

First Two Decades. The children reported by Landtman, Louhimo, and Wallgren (1966) were unselected: only one had aortic valvotomy during the follow-up, though others had this later at the hospital for adults. Of the 102 patients, followed for 510 patient-years, 6 died: 2 suddenly, 3 from congestive failure, and 1 from endocarditis. The 
TABLE V

CALCULATED EXPECTED DEATHS AND SURVIVORS FROM 1000 SUBJECTS WITH CONGENITAL AORTIC STENOSIS ALIVE AT I YEAR

\begin{tabular}{|c|c|c|c|c|c|c|c|}
\hline \multicolumn{2}{|l|}{ Ages } & \multirow{2}{*}{$\begin{array}{r}\text { At } \\
10\end{array}$} & \multirow{2}{*}{$\begin{array}{l}\text { At } \\
20 \\
15\end{array}$} & \multirow{2}{*}{$\begin{array}{l}\text { At } \\
30 \\
28\end{array}$} & \multirow{2}{*}{$\begin{array}{l}\text { At } \\
40\end{array}$} & \multirow{2}{*}{$\begin{array}{l}\text { At } \\
50 \\
88\end{array}$} & \multirow{2}{*}{$\begin{array}{r}\text { At } \\
60 \\
198\end{array}$} \\
\hline Normal subjects (1000) & Dead & & & & & & \\
\hline $\begin{array}{l}1000 \text { subjects with congenital aortic } \\
\text { stenosis living at } 1 \text { year }\end{array}$ & $\begin{array}{l}\text { Dead } \\
\text { Living }\end{array}$ & $\begin{array}{l}103 \\
897\end{array}$ & $\begin{array}{l}206 \\
794\end{array}$ & $\begin{array}{l}(351) 415 \\
(649) 585\end{array}$ & $\begin{array}{l}(547) 590 \\
(453) 410\end{array}$ & $\begin{array}{l}(757) 779 \\
(243) 221\end{array}$ & $\begin{array}{l}(902) 911 \\
(98) 89\end{array}$ \\
\hline
\end{tabular}

The figures within the double lines are less accurate because they depend on assumptions about how long those operated on would have lived without this.

mortality rate of 1.2 per cent per annum, with 0.4 per cent for sudden deaths, seems likely to be near the truth.

Edwards and Jones (1962) reported 5 deaths from heart failure and 6 sudden deaths in 115 children. I am greatly indebted to Richard Jones for calculating that they had been followed for 1395 patientyears, most of them from infancy. This gives a rather lower mortality rate of 0.8 per cent per annum (probably because some with more severe stenosis were removed from follow-up by having aortic valvotomy) and the same rate of 0.4 per cent for sudden deaths.

Patients at hospital clinics naturally show a higher mortality as they include fewer of the less severe cases. My series with a mortality rate of 1.6 per cent per annum is the nearest to the first two, perhaps because it included more patients referred mainly because of their murmurs.

Marquis and Logan (1955) had 5 deaths, 3 sudden at 9,11 , and 15 years. Braverman and Gibson (1957) followed 73 of 85 children, under 16 when first seen, for about 4 years. Of these, 44 could lead a normal life with their fellows, 14 were moderately handicapped, and 9 were severely disabled, figures that are similar to mine. The other 6 died, 5 suddenly, between 3 and 14 years.

Ongley et al. (1958) found 4 sudden deaths among 67 children at 5, 8, 13, and 14 years. All these 4 had $T$ wave inversion or S-T depression in the left chest leads, and I think only 15 of the 67 showed these changes.

For these 429 children, followed for an average of nearly 7 years, the mortality rate was 1.4 per cent per annum, including 0.9 per cent for the sudden deaths. This means that 23 per cent would die in the first two decades, more than half of them suddenly. These figures reflect the need for a really satisfactory operation if such lives are to be saved.

In calculating the expectation of life for the first two decades, it seemed fairest to use the mortality of 1.2 per cent per annum from the unselected series of Landtman et al. (1966), and these figures are shown in Table V, starting with 1000 living subjects at the age of 1 year. Most other series would give a less favourable expectation.

Later Decades. My own series seems to be the only one for these later calculations. The account of the condition of patients in various decades given above can leave no doubt that congenital aortic stenosis is a progressive condition, and this is supported by the collective series of Hohn et al. (1965). Most of their patients had operations, presumably those with the more severe stenosis; only 66 of the 233 were followed without operations for an average period of 7 years. Even so, the mortality from sudden death was 0.4 per cent per annum. Of the 38 patients with no symptoms, half developed symptoms or cardiographic abnormalities in these 7 years. Only 4 had catheterization repeated after 2 years or so, and in 3 of these the gradient had increased by from 20 to $40 \mathrm{~mm}$. $\mathrm{Hg}$ (catheterization may, of course, have been repeated mainly in those who seemed to be doing badly).

My own results for the third decade show a mortality rate similar to the figure for the first two decades. It is lowered by the patients who had aortic valvotomy, as not many would have lived very long without this. Those having operations in the first four decades must be considered individually as regards their expectation of life.

Of the 3 patients having valvotomy in the first decade, 1 could hardly have lived beyond the second, and 1 beyond the third decade, but 1 might have lived for a long time. Of the 9 in the second decade, it seems most unlikely that more than 3 would have lived beyond the fourth decade. I have assumed 1 death in the second, 5 in the third, and 3 in the fourth decade. Of the 2 in the third decade, 1 would probably have died in the fourth decade, and 1 in the fifth decade. Of the 5 having operations in the fourth decade, 1 would probably have died in the fourth, 2 in the fifth, and 2 in the sixth decade. Of the 7 having operations in the fifth decade, I have counted only 1 as dying in the fifth, 4 in the sixth, and 2 in the seventh decade. After the fifth decade, however, the mortality was 
so high that one or two extra deaths had much less effect.

These extra deaths, which have been estimated conservatively, with appropriate additions to the number of patient-years, would increase the mortality rates to $3.2,3.7,6.4$, and 8.7 per cent per annum in the third to sixth decades, respectively. Hohn et al. (1965) found that only one-quarter of their patients had gradients over $100 \mathrm{~mm}$. $\mathrm{Hg}$, which emphasizes the severity of the stenosis in my patients who had operations. It has, therefore, seemed best to reduce these figures slightly.

In calculating the expectation of life, I have used two alternative figures for the third decade, 2.0 in brackets in Table $\mathrm{V}$ because I think this much too low, and 3.0 per cent without brackets. I have used 3.5 per cent for the fourth decade, 6.0 per cent for the fifth, and 8.7 per cent for the sixth decade. The use of the lower mortality rate in the third decade does not make much difference by the sixth decade, because it leaves more subjects exposed to the higher mortality rates later.

The top line in Table V shows the expected number of deaths, calculated from the English Life Table No. 11 (Registrar General, 1957) for a population that is normal except that it consists of three men for each woman to be comparable with the subjects with aortic stenosis. The second line in Table V shows the deaths among those with congenital aortic stenosis. They are about 10 to 14 times as many as normally at all ages up to the $40 \mathrm{~s}$. Obviously the figures from 30 onwards are less reliable than those for the first two decades because they depend on certain assumptions. I think, however, that they are fairly correct, except that they show too many patients surviving to 60 years. My own experience is that this is nearer 3 per cent than the 9 per cent shown.

Table $\mathrm{V}$ shows that nearly 60 per cent $(58 \cdot 5)$ of the subjects with congenital aortic stenosis are living at 30 years, but that nearly 60 per cent (59) have died by 40 years. Corresponding to this, the mean age of death is 35 years. This is a little below the 38.7 years for my own patients, because the former includes some deaths that were assumed, had there been no operations.

\section{SUDDEN DEATHS}

More than half the deaths in children (Table IV), and more than one-third of all our deaths, were sudden. One of the 4 adults who lived 10 years after the onset of effort syncope, and the 4 boys who died suddenly, will be described briefly.

Case 39 consulted me because he had lost consciousness while running for a bus, at the age of 39 . His blood pressure was $110 / 85 \mathrm{~mm}$. $\mathrm{Hg}$ and his aortic valve was calcified, though he had served in the R.A.F. from the age of 34-38 without comment. After three similar attacks in a year, the warning sensation taught him how to avoid them. He now had angina also, but with the use of trinitrin he managed his sedentary work for another 9 years. When 49 , angina became more frequent and he now had $T$ wave inversion in V5 and V6 as well as the left ventricular hypertrophy that had been present for 10 years. While waiting for aortic valvotomy, he died suddenly during his journey home after work. Probably he had severe pain while in the train, because he had time to get out at an intermediate station but no time to ask for help. There was no necropsy.

Cases 6, 23, and 41 resembled each other in most features. They had aortic stenosis with small pulse pressures of $30 \mathrm{~mm}$. $\mathrm{Hg}$ or less. In only one was the heart slightly enlarged (cardiothoracic ratio $52 \%$ ). All had signs of left ventricular hypertrophy (mean $32+29)^{\star}$, with about $2 \mathrm{~mm}$. T wave inversion or S-T depression in leads I, V5, and V6. All were breathless on running, but Case 41 said it was only because he ran so fast. The only other symptom was effort syncope in Case 23 (about 6 attacks, but only one after I saw him, when he was chased by a dog). None gave a history of angina, but perhaps they were not questioned carefully enough about this. At that time, they seemed too well for valvotomy, yet within 2-4 years they had all died. Case 6, aged 16, died as he was walking into his classroom at school; Case 23, aged 9, died suddenly at school; and Case 41, aged 9, died almost instantaneously in the lavatory, after saying a few cheerful words to his mother on returning from school by car.

Case 43, aged 1-12, was already dyspnoeic at 3 , and more so at 6 ; left ventricular puncture showed an aortic gradient of only $36 \mathrm{~mm}$. Hg. (142/8 to $106 / 80 \mathrm{~mm}$. $\mathrm{Hg})$. At the age of 11 he had angina, and at 12 his first syncopal attack. There was no more left ventricular hypertrophy $(30+12)^{\star}$ than at 5 years, and no ST-T abnormalities. Yet four months later he died suddenly when out walking with his father.

In this boy, and in the 2 of the other 3 who had necropsies, severe aortic valve stenosis and left ventricular hypertrophy were the only abnormalities.

Comment. The first 3 boys probably had a gradient of over $60 \mathrm{~mm}$. Hg (Table II) and would, now, have had an operation. In Case 43, the absence of any ST-T abnormalities seemed reassuring, and I still think sudden death is unusual without such signs.

Until I knew of the deaths of the first three in 1955-57, I did not realize its frequency in congenital aortic stenosis though $I$ had been interested in the association of effort syncope and calcific aortic stenosis for a long time (Campbell, 1937). When Marvin and Sullivan (1935) showed that mixed arrhyth-

* The figures in brackets are the size in $\mathrm{mm}$. of $\mathrm{S}$ in $\mathrm{V} 1$ and of $\mathbf{R}$ in V5 or V6. 
mias occurred in some attacks of effort syncope, I tried to record them in a patient who was prone to such attacks. He showed no arrhythmia and no syncope on this occasion, and when I learned that his next attack of effort syncope had proved fatal I was discouraged from further observations. Effort syncope seems to be the only useful warning symptom, but is far from being a constant one. In discussing its association with calcific aortic stenosis, Campbell (1948) thought the S-T abnormalities pointed to a reduced coronary blood flow that might be the cause of ventricular fibrillation or other arrhythmias. This is probably the general view. It was accepted by Leak (1959) when he was discussing the small number of reported cases with electrocardiograms: in his case the arrhythmia was cardiac arrest.

The variety of arrhythmias that may cause death in Adams-Stokes attacks or after cardiac infarction is now well recognized, and this is the case with the sudden deaths of aortic stenosis also, though ventricular fibrillation is probably the most frequent. Hancock and Fleming (1960) found it hard to correlate effort syncope with any of their physiological data except the height of the left ventricular enddiastolic pressure.

I see no easy answer about how these sudden deaths may be prevented. But no child should be left more than a year without a repeat electrocardiogram, and any deterioration should lead to a consideration of aortic valvotomy. Many of these earlier patients were reviewed only at intervals that were much too long.

Case 21, aged 7-17, died with ventricular fibrillation after an operation, but is quoted here to show how carefully children must be questioned to elicit a history of angina. When 7 , she seemed well and had left ventricular hypertrophy without $T$ wave inversion, but 4 years later $\mathrm{T}$ was inverted in $\mathrm{V} 6$ and V7. At 14, she admitted no symptoms except being more breathless than other girls while climbing stairs at school. When asked what stopped her on the most strenuous exertion, she described an unpleasant tight feeling in the centre of the chest, felt last when dancing energetically, enough to make her sit down for a few minutes: sometimes the same feeling had made her stop while running fast. The $T$ waves were now inverted in leads $I, V 4$, and V5, and her heart was larger (cardiothoracic ratio $49-53 \%$ ). A year later, left ventricular puncture showed a very large gradient, $225 / 20$ to $90 / 65 \mathrm{~mm}$. Hg. She had to wait two more years for operation, when the valves were found to be normal, but there was severe subvalvar stenosis. A reduction of the gradient to $11 \mathrm{~mm}$. $\mathrm{Hg}$ did not prevent her death on the third day with recurrent fibrillation. At necropsy, the heart weighed $800 \mathrm{~g}$. (age 17). The subvalvar stenosis had been adequately resected and the normality of all the valves was confirmed.

\section{SOMe Characteristic Histories}

Some readers may get a clearer picture from a few characteristic patients than from the figures already given. I can recall almost all these patients, though a few are now no more than case notes. First, examples of deterioration in each of the first six decades will be given. This change was reached in stage (3), with the onset of more serious symptoms or signs. Left ventricular failure might occur soon, or not for some years, but was generally followed quickly by congestive heart failure unless sudden death struck earlier. This is so important that it has been dealt with separately.

The first stage, with no special symptoms or warning signs, may last only a few years, or more than 40 years as in Case 52. This patient led the most normal life I know for anyone with congenital aortic stenosis, with only slight signs and symptoms until the sixth decade. The other stages also can be short or long.

Some patients showing the effects of aortic regurgitation and bacterial endocarditis come next, and finally, some who have been followed for more than a decade and are still doing well. There would have been more in this group had I found time to write this paper in 1958, but the delay has made me more certain that congenital aortic stenosis is nearly always progressive, though often slowly over several decades. Case 30, whom I first saw as a boy of 12 in 1932, and who died at 44 in 1964, with his progress through angina, left ventricular strain, and heart failure, seems to me to have run the most typical course. The early signs of left ventricular strain may remain stationary for more than a decade, though they may progress rapidly:

Deterioration in Each Decade. Patients deteriorating in the first two decades must have had severe stenosis from birth, and the 2 examples both had a large heart: this is a late sign and uncommon at this age. There was 1 other with severe stenosis in the first, and at least 4 others in the second decade. All these 7 had aortic valvotomy. Deterioration in the third, fourth, and fifth decades is much more common. After this there are not so many survivors. A patient in whom deterioration was unusually sudden between the age of 29 and 31 is described (Case 53). Cases 26 and 28 with necropsies have already been described.

First Decade. Case 45 (2)+. Male, aged 2-6. At 2, noticeably dyspnoeic. At 3 , left ventricular hypertrophy $(23+16)^{\star}$ and $T$ wave inverted in lead $I$ and flat in V5 and V6. At 4, angina pectoris. At 5, angina frequent and severe, much more breathless, and heart

+ The figure in parentheses denotes the age at which the murmur was first known to be present. 
larger (cardiothoracic ratio $59 \%$ instead of $52 \%$ ); $\mathrm{T}$ wave now inverted in leads I, V5, and V6; average blood pressure $94 / 69 \mathrm{~mm}$. Hg. At 6, aortic valvotomy reduced the peak systolic gradient from 128 to $12 \mathrm{~mm}$. $\mathrm{Hg}$.

Second Decade. Case 48 (2)†. Female, aged 3-14. At 3, left ventricular hypertrophy not decisive, and T waves normal. At 9, left ventricular hypertrophy $(15+27)^{\star}$ and $\mathrm{T}$ wave flat in V6; dyspnoea first noticed. At 11 , worse with heart enlarged (cardiothoracic ratio $56 \%$ ) and $T$ wave flat in leads I, V5, and V6. At 13, severely dyspnoeic, $T$ wave deeply inverted in leads $I$, V5, and V6. At 14, operation for subvalvar stenosis with a gradient of $180 \mathrm{~mm}$. $\mathrm{Hg}$.

Third Decade. Case $24(8) \dagger$. Male, aged 16-29. At 16 , active life without symptoms, but moderate left ventricular hypertrophy with some $T$ wave inversion in V3-V5; not much worse at 26 . At 28, still walking up to 10 miles, but some dyspnoea and angina when hurrying; left ventricular hypertrophy increased $(38+24$ to $41+34)^{\star}$ and $T$ wave inversion much deeper, $10 \mathrm{~mm}$. in V3 and V4, and 3-4 mm. in leads $I$, V5, and V6. At 29 , with aortic valvotomy, a gradient of $84 \mathrm{~mm}$. $\mathrm{Hg}$ was reduced to $8 \mathrm{~mm}$. $\mathrm{Hg}$.

Sudden Deterioration. Case. 53 (3) †. Male, aged 13-32. At 13, no symptoms; a colleague found the electrocardiogram normal ( 3 leads) and diagnosed ventricular septal defect. At 29, still very active, with no symptoms, and he was seen only because aortic stenosis was suspected after his mother had been seen (Case 52, described below). Some left ventricular hypertrophy with $2 \mathrm{~mm}$. S-T depression in V5 and V6 (already rather worse than his mother). Clearly I was mistaken in allowing him to continue playing energetic games as at 31 he consulted Dr. Charles Baker because he was so dyspnoeic and felt he would lose consciousness while playing games. The heart was larger (cardiothoracic ratio $58 \%$ instead of $52 \%$ ) and $\mathrm{T}$ waves much more deeply inverted in V5 and V6. At operation a few months later, since he was then verging on heart failure, the gradient was reduced from 128 to $20 \mathrm{~mm}$. $\mathrm{Hg}$.

Fourth Decade. Case $30\left({ }^{\star} 2\right)+$. Male, aged 12-44. At 12, no symptoms. Pulmonary stenosis diagnosed on systolic murmur and thrill, with normal electrocardiogram ( 3 leads). The changes at the various ages were as follows: at 18, slight dyspnoea and aortic stenosis; at 28 , slight angina, left ventricular hypertrophy, and slight $T$ wave inversion in lead $I$; at $33, T$ wave inverted in leads I, V5, and V6; at 37, dyspnoea and angina worse, heart of normal size; at 38, congestive heart failure, with good recovery but occasional relapses; at 43 , persistent congestive heart failure. At 44 he died after operation: pressure gradient, $95 \mathrm{~mm}$. $\mathrm{Hg}$; heart weight, $680 \mathrm{~g}$.; valve bicuspid.

Case 2 ( 6 months). $\dagger$ Female, aged 18-35. Very well up to age 18 . At 24, left ventricular hypertrophy $(37+11)^{\star}$ and slight S-T depression in leads I and V4-6, but had a pregnancy with no difficulty. At 28 , soft aortic diastolic murmur sometimes heard. At 31, occasional angina, but no change in the electrocardiogram. At 35, angina rather worse, also aortic regurgitation; blood pressure $150 / 85$ instead of $127 / 93 \mathrm{~mm}$. $\mathrm{Hg}$. The aortic gradient was then $100 \mathrm{~mm}$. Hg. Successful valvotomy.

Fifth Decade. Case 71 (15)†. Female, aged 34-62. At 34, dyspnoea had become more noticeable. At 40 , some angina with flat $T$ wave in lead I. Age 44-48, angina increasing and $T$ wave in lead $I$ inverted, but only slight left ventricular hypertrophy $(17+20)^{\star}$. Aortic valve calcified at age 44 (or earlier). At 51 , heart larger (cardiothoracic ratio $52 \%$ ), and $\mathrm{T}$ wave inversion in V5 and V6. At 55, left bundle-branch block and first attack of left ventricular failure; she was still working as a dispenser and running her home; blood pressure little changed, averaging $135 / 97 \mathrm{~mm}$. $\mathrm{Hg}$ from 34 to 48 , and $146 / 106 \mathrm{~mm}$. $\mathrm{Hg}$ from 50 to 60 years. From 58 to 62 , recurrent attacks of congestive heart failure. Necropsy was not performed.

Sixth Decade. Case 52 (3)†. Female, aged 45-63. Active life and playing tennis for many years. Rarely aware of the heart until some dyspnoea on hills was experienced at 43 . From 45 to 53, left ventricular hypertrophy $(24+16)$ * with biphasic $T$ wave in lead I and slight S-T depression in V5 and V6; neither these signs nor her dyspnoea changed during these 8 years. At 58, dyspnoea rather worse, pulse pressure smaller, $140 / 105$ instead of $146 / 91 \mathrm{~mm}$. $\mathrm{Hg}$, and $\mathrm{T}$ wave inversions of $5 \mathrm{~mm}$. in lead I and $3 \mathrm{~mm}$. in V5 and V6; gradient probably $>50 \mathrm{~mm}$. $\mathrm{Hg}$ (see Table II). She declined an operation. At 61 , she had married again and moved to a hillier district; dyspnoea was no worse, but the $T$ wave inversion was deeper. At 63, she died suddenly on her way to a wedding.

Aortic Regurgitation. An aortic diastolic murmur without much widening of the pulse pressure is generally unimportant. One boy had such a murmur when 8 years old, with a pulse pressure of $55 \mathrm{~mm}$. Hg. Yet, at 21 this is no wider, left ventricular hypertrophy $(24+25)^{\star}$ has not increased, he has no S-T or T wave abnormalities, and no symptoms except dyspnoea on heavy exertion.

Another boy with such a murmur at 3 years is still without symptoms at 23 . But his pulse pressure is now widening (127/78 instead of $113 / 83 \mathrm{~mm}$. $\mathrm{Hg}$ ), and for the past 3 years he has had slight S-T depression in V5 and V6. His outlook has become uncertain.

In Case 54, aortic regurgitation became the main cause of his symptoms, and he died at 52 years. A diastolic murmur was heard in nearly one-third of the patients of Hohn et al. (1965), but only onetwentieth were thought to have important aortic regurgitation. Most of those with a pulse pressure of much more than $60 \mathrm{~mm}$. $\mathrm{Hg}$ had had subacute bacterial endocarditis. 
Case 54 (3)†. Male, aged 24-52. At 24, aortic stenosis, blood pressure $150 / 90 \mathrm{~mm}$. $\mathrm{Hg}$; normal cardiogram (3 leads). At 36 , aortic stenosis, slight aortic regurgitation, blood pressure $155 / 70 \mathrm{~mm}$. $\mathrm{Hg}$, electrocardiogram not taken. At 44, aortic stenosis, aortic regurgitation, blood pressure $190 / 70 \mathrm{~mm}$. $\mathrm{Hg}$, left ventricular hypertrophy, $T$ wave inverted in leads $I$, V5, and V6; valves calcified. At these 3 visits he was attended by 3 of my senior colleagues: all emphasized the absence of mitral stenosis and of a rheumatic history, but diagnosed his condition as rheumatic. At 47 he had increasing dyspnoea, angina, and a larger heart. At 52, left ventricular failure after heavy gardening and house decorating. Blood pressure $148 / 65 \mathrm{~mm} . \mathbf{H g}$ (average, 47-52 years). Died 1 month later, with no necropsy.

Subacute bacterial endocarditis is still a grave danger to patients with aortic valve disease since it may cause or increase aortic regurgitation to a severe degree. Two examples follow (see also Case 77B below). Three others lost ground after an attack, but two recovered without any damage. This means that the risk of an attack is at least 0.9 per cent per annum.

Case $80 B$ (35, at examination for life assurance)t. Male, 35-46. Continued his normal activity with no symptoms till age 40 , when he had subacute bacterial endocarditis and was for 6 months in hospital. After this, increasing dyspnoea and aortic regurgitation. At 43, left ventricular failure. A year later, congestive heart failure, which recurred until death at 46 . At necropsy the heart weighed $920 \mathrm{~g}$. There was severe stenosis and regurgitation of a rigid, calcified, bicuspid aortic valve. Embolic infarcts of the kidney and tubular degeneration.

Case 57 (4)†. Male, aged 13-15. At 13, only slight aortic stenosis. At 15, subacute bacterial endocarditis; the infection was cured (and the stenosis), but he developed heart failure from gross aortic regurgitation and died while still in hospital.

Patients Still Doing Well. These can be set against the many who have lost ground or who have died. Of those seen first as school children, 14 with a mean age of 9 are still well now, with a mean age of 25 years. A few of them are developing slight signs of left ventricular hypertrophy, but the majority are without this or any symptoms. One, now 33, has served in the army in North Africa without difficulty. Cases 4 and 59 are described below as we now know their aortic gradients. Another patient was getting on well from 12 to 44 years until he had a recrudescence of tuberculosis from which he died (Case 70). There were only 3 seen first in their 20s who got on well for as long as this. Cases 20 and 77B are described below. Case 19 was followed from 21 to 38 years and was still fairly well but had developed slight $T$ wave inversion in lead I. She may have died suddenly, as I cannot trace her; she lived alone and attended hospital regularly.

Case 4 (10 months) t. Male, aged 3-16. At 16, he was still leading an active life without any symptoms. He had no ST-T abnormalities and left ventricular hypertrophy $(29+20)^{\star}$ was unchanged from age 5-16. At 13, his gradient was $52 \mathrm{~mm}$. $\mathrm{Hg}$ (from $140 / 4$ to $88 / 57 \mathrm{~mm}$. $\mathrm{Hg}$ ).

Case 59 (4) †. Female, aged 6-17. At 17 she was doing hard work in stables and she had never experienced symptoms; there were no ST-T abnormalities and no left ventricular hypertrophy $(16+14)^{\star}$. At 17 , her gradient was found to be $28 \mathrm{~mm}$. $\mathrm{Hg}$ (from 162/10 to $134 / 80 \mathrm{~mm}$. $\mathrm{Hg}$ ).

Case $20(5)+$. Female, aged 23-37. Seen at 23 during a normal pregnancy. Slight left ventricular hypertrophy $(29+9)^{\star}$. At 27 , and again at 37 , she was still well; no increase in left ventricular hypertrophy; no ST-T abnormalities. Her stenosis must be slight to moderate, but without a knowledge of her gradient her long-term outlook is uncertain.

Case 77B (27)t. Male, aged 27-49. A murmur was first noted on his discharge from the R.A.F. From 27 to 39 he led a normal life with no symptoms except when doing heavy digging. Systolic thrill rarely felt except after exercise. Heart not enlarged. From 40-48, equally good progress; no significant left ventricular hypertrophy $(15+16)^{\star}$, good $\mathrm{T}$ waves, and average blood pressure $106 / 76 \mathrm{~mm}$. Hg. No calcification of the aortic valve was seen at 48 years.

A few months after his visit to hospital in 1966, he had a dental extraction without penicillin cover, and was subsequently admitted with bacterial endocarditis (Streptococcus viridans). After this he became increasingly breathless, and in February 1967 he was admitted with congestive heart failure which took a month to relieve. There was gross aortic regurgitation, and catheterization showed an aortic gradient of $30 \mathrm{~mm}$. Hg; left ventricular end-diastolic pressure $25 \mathrm{~mm}$. $\mathrm{Hg}$; for the first time, cardiographic signs of left ventricular strain. He is now 49 (July 1967), and Mr. D. N. Ross has carried out an operation for aortic valve replacement as his failure readily returns. There was a typical bicuspid valve with a fused intercoronary commissure and a large non-coronary cusp. The valve was pliable and seemed non-calcified. The regurgitation was due to partial detachment of the posterior commissure between the left and non-coronary cusps. Professor R. E. B. Hudson reported that the histological appearances were consistent with a congenital bicuspid valve with fibrous thickening and very early calcification near the commissure of one cusp. It seems reasonable to assume that slight aortic stenosis developed from a congenital bicuspid valve that became more fibrous, and that had this not been attacked by subacute bacterial endocarditis he would still be doing well. 


\section{SUMMARY AND CONCLUSIONS}

As operations for aortic stenosis become more frequent, knowledge of the natural history of the condition becomes more difficult to acquire. These remarks are based on 87 patients with valvar or subvalvar (one-fifth) congenital aortic stenosis. Only one-quarter were female.

Some patients were first seen in the 1930 s, but most in 1946-57. All but 6 of those still living were reviewed in 1958, and some later up to 1966 through the kindness of my colleagues. The follow-up was terminated by death in 22 patients and by aortic valvotomy in 27 , whether these last did well or badly or died. The follow-up averaged 9 years and was between 20 and 32 years in 8 patients-a total of 782 patient-years.

None of these patients were infants, when the mortality rate is very heavy, $23 \pm 5$ per cent in the first year. It falls to 1.2 per cent for the rest of the first two decades and then rises to about $3 \cdot 0,3.5$, 6.0 , and 8.5 per cent per annum in the third to sixth decades, respectively. After this there are few surviving patients. My calculations suggest that nearly 60 per cent were living at 30 years, while at 40 years nearly 60 per cent had died.

The risk of sudden death is at least 0.4 per cent per annum in the first three decades and twice this in those seen at hospital. It is greater than this in later decades. This risk seems the most urgent reason for finding a really curative operation.

Bacterial endocarditis attacks about 0.9 per cent of patients with congenital aortic stenosis each year. Though now it can usually be cured, it remains a serious hazard because of the progressively severe aortic regurgitation it so often leaves. Otherwise, aortic regurgitation is not usually of much importance except, of course, after aortic valvotomy.

In each of the first three decades, between 40 and 50 per cent of our patients were getting on very well, a quarter felt well but had some unfavourable signs, and a fifth had serious signs and symptoms. In the fourth and fifth decades the number who were well was only half this, and the number doing badly or dying about twice as many.

No patients survived the sixth decade without serious unfavourable signs or symptoms, and only two reached the seventh decade (dying at 62 and 63 years of age). It is possible that some of my younger patients now doing well may live beyond this age but experience with older patients who were doing very well (Cases 52, 71, and 77B) makes me think this unlikely. In those who die at 70 or 80 years with lone aortic stenosis, this is more likely to be due to calcification of a bicuspid valve, or of a valve that was originally normal and tricuspid.

It is some satisfaction that so many can lead an active life through the first three decades. This must not blind us to the fact that congenital aortic stenosis is a progressive disorder. The worsening may be the stenosis becoming more severe, or its effect on the heart muscle, or, more often, both: it may come quickly, or only after several decades.

When surgical treatment of aortic stenosis is as safe and as curative as the division of a persistent ductus arteriosus, it will be readily accepted as a routine, but at present this is not so. All patients must, therefore, be examined regularly, children at least once a year, and any signs of worsening must be assessed with a wide view of all aspects of the patient.

I wish to thank my colleagues who enabled me to extend this follow-up after 1957-58, especially Drs. C. Baker, R. Kauntze, and D. C. Deuchar at Guy's Hospital, and Dr. A. Leatham, Mr. D. N. Ross, and Dr. L. Resnekov at the National Heart Hospital. I am grateful to Mr. Ross and Professor R. E. B. Hudson for their reports on the valve of Case 77B and to Dr. S. Oram for the necropsy of Case 28.

\section{REFERENCES}

* Indicates the series used for the sex incidence and for the proportion of valvar and subvalvar types of aortic stenosis.

* Abbott, Maude (1936). Atlas of Congenital Cardiac Disease. American Heart Association, New York.

Abdin, Z. H. (1958). The electrocardiogram in aortic stenosis. Brit. Heart f., 20, 31.

Baker, C. G., and Campbell, M. (1956). The results of valvotomy for aortic stenosis. Lancet, 1, 171.

* - , and Somerville, Jane (1964). Results of surgical treatment of aortic stenosis. Brit. med. F., 1, 197.

* Braverman, I. B., and Gibson, S. (1957). The outlook for children with congenital heart disease. Amer. Heart $\mathcal{F}$. 53, 487

Brock, R., Milstein, B. B., and Ross, D. N. (1956). Percutaneous left ventricular puncture in the assessment of aortic stenosis. Thorax, 11, 163.

Brown, J. W. (1950). Congenital Heart Disease, 2nd ed. Staples Press, London and New York.

Campbell, M. (1937). Aortic valve diseases. In The British Encyclopaedia of Medical Practice, Vol. 6, p. 349. Butterworth, London.

- (1948). Some rarer causes of attacks of unconsciousness. Clin. F., 77, 161.

- (1968). Calcific aortic stenosis and bicuspid aortic valves. Brit. Heart 7., 30, 606.

- , and Kauntze, R. (1953). Congenital aortic valvular stenosis. Brit. Heart f., 15, 179.

Carlgren, L.-E. (1959). The incidence of congenital heart disease in children born in Gothenburg 1941-50. Brit. Heart f., 21, 40.

Christian, H. A. (1933). Congenital and acquired aortic stenosis in adults. Med. Clin. N. Amer., 16, 773.

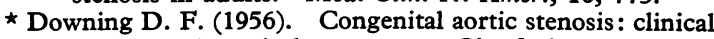
aspects and surgical treatment. Circulation, 14, 188.

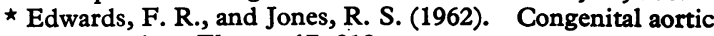
stenosis. Thorax, 17, 218. 
Epstein, E. J., and Coulshed, N. (1964). Assessment of aortic stenosis from the external carotid pulse wave. Brit. Heart F., 26, 84.

Fleming, P., and Gibson, R. (1957). Percutaneous left ventricular puncture in the assessment of aortic stenosis. Thorax, 12, 37.

* Gallavardin, L. (1936). Le rétrécissement aortique non rhumatismal pur ou très prédominant (d'après 50 observations personelles). F. Méd. Lyon, 17, 593.

Gamboa, P., Hugenholtz, P. G., and Nadas, A. S. (1965). Comparison of electrocardiograms and vectorcardiograms in congenital aortic stenosis. Brit. Heart f., 27, 344.

Grishmann, A., Steinberg, M. F., and Sussman, M. L. (1947) Congenital aortic and subaortic stenosis with associated anomalies of the aorta. Med. Clin. N. Amer., 31, 543.

* Hancock, E. W., and Fleming, P. R. (1960). Aortic stenosis. Quart. F. Med., 29, 209.

* Hohn, A. R., Van Praagh, Stella, Moore, A. A. D., Vlad, P., and Lambert, E. C. (1965). Aortic stenosis. Circulation, 32, Suppl. III, p. 4.

Keith, J. D., Rowe, R. D., and Vlad, P. (1958). Heart Disease in Infancy and Childhood. Macmillan, New York.

Kiloh, G. A. (1950). Pure aortic stenosis. Brit. Heart. F., $12,33$.

* Landtman, B., Louhimo, I., and Wallgren, E. I. (1966). Congenital aortic stenosis in children: follow-up of 103 conservatively treated. Acta chir. scand., Suppl. $356 \mathrm{~B}$.

Leak, D. (1959). Case report. Effort syncope in aortic stenosis. Brit. Heart F., 21, 289.

MacMahon, B., McKeown, T., and Record, R. G. (1953). The incidence and life expectation of children with congenital heart disease. Brit. Heart f., 15, 121.

* Marquis, R. M., and Logan, A. (1955). Congenital aortic stenosis and its surgical treatment. Brit. Heart F., 17, 373.

Marvin, H. M., and Sullivan, A. G. (1935). Clinical observations upon syncope and sudden death in relation to aortic stenosis. Amer. Heart f., 10, 705.

* Ongley, P. A., Nadas, A. S., Page, M. H., Rudolph, A. M., and Starkey, G. W. B. (1958). Aortic stenosis in infants and children. Pediatrics, 21, 207.

Registrar General (1957). Decennial Supplement, England and Wales, 1951: Life Tables, pp. 31-34.

Soulié, P., Caramanian, M., Morin, B., Acar, G., and Forman, J. (1964). Embolies calcaires du rétrécissement aortique calcifié. Arch. Mal. Coeur, 57, 633.

Thursfield, H., and Scott, H. W. (1913). Sub-aortic stenosis. Brit. F. Child. Dis., 10, 104.

Wood, P. (1950). Diseases of the Heart and Circulation. Eyre and Spottiswoode, London.

Young, D. (1944). Congenital subaortic stenosis. Amer. Heart $\mathcal{F}, 28,440$. 